Cronfa - Swansea University Open Access Repository

This is an author produced version of a paper published in :

Theory, Culture \& Society

Cronfa URL for this paper:

http://cronfa.swan.ac.uk/Record/cronfa16181

\title{
Paper:
}

Smith, R. (2014). Dubai in extremis. Theory, Culture \& Society, 31(7/8), 291-296.

http://dx.doi.org/10.1177/0263276414547775

This article is brought to you by Swansea University. Any person downloading material is agreeing to abide by the terms of the repository licence. Authors are personally responsible for adhering to publisher restrictions or conditions. When uploading content they are required to comply with their publisher agreement and the SHERPA RoMEO database to judge whether or not it is copyright safe to add this version of the paper to this repository. http://www.swansea.ac.uk/iss/researchsupport/cronfa-support/ 


\title{
Theory, Culture \& Society \\ http://tcs.sagepub.com/
}

\section{Dubai in extremis}

Richard G Smith

Theory Culture Society 2014 31: 291 originally published online 17 September 2014 DOI: $10.1177 / 0263276414547775$

The online version of this article can be found at:

http://tcs.sagepub.com/content/31/7-8/291

\author{
Published by: \\ ()SAGE \\ http://www.sagepublications.com \\ On behalf of: \\ Theory, Culture and Society
}

Additional services and information for Theory, Culture \& Society can be found at:

Email Alerts: http://tcs.sagepub.com/cgi/alerts

Subscriptions: http://tcs.sagepub.com/subscriptions

Reprints: http://www.sagepub.com/journalsReprints.nav

Permissions: http://www.sagepub.com/journalsPermissions.nav

>> Version of Record - Dec 2, 2014

OnlineFirst Version of Record - Sep 17, 2014

What is This? 


\section{Dubai in extremis}

\author{
Richard G Smith
}

Swansea University
Theory, Culture \& Society 20I4, Vol. 3I(7/8) 29I-296

(C) The Author(s) 2014

Reprints and permissions: sagepub.co.uk/journalsPermissions.nav DOI: |0.1|77/02632764|4547775

tcs.sagepub.com

\begin{abstract}
Dubai, the most extreme example to date of a realized neo-liberal capitalist urban utopia, is perhaps at its point of death. That is to say that, barring suicide, the only hope Dubai's bonded labour - those tricked, forced and exploited into negated lives of low-paid wage servitude - have of losing their chains, given the emirate's resilience to objections and protests from a multitude of commentators and activists, seems to be the stalling of construction, the falling demand for building projects - mega or otherwise - that the latest major financial crisis and economic recession necessitates.
\end{abstract}

\title{
Keywords
}

bonded labour, event, global city, globalization, mega-projects, perfection, utopia

'Dubai is seemingly on track to join Hong Kong and Singapore as another "global city" that will soon serve as a major command point in the organisation of the world economy', writes Christopher M. Davidson (2008: 1-2). Once a forgotten fishing settlement on the Arabian Peninsula, the city-state of Dubai, one of seven emirates constituting the United Arab Emirates (UAE), has dedicated itself - during the long globalization-driven economic boom from 1991 to 2007 - to becoming a glamour city of transnational capital, to eclipsing the Lebanon to become the premier commercial city and financial centre of Arabia and the Near East.

An urban experiment-in-the-making, and anathema to the claims of historians such as Fernand Braudel that urban forms tend to change slowly, Dubai has rapidly planned and built itself, from what was little more than a flat desert tabula rasa only 20 years ago into the Arabian blue-chip 'global city': an entertainment and tourist hub, a business and finance centre, a high-tech Mecca, and a shipping and trading entrepôt. And not a global city like New York or London, but the perfect global city - a neo-liberal urban utopia, a conservative small-government 
euphoric capitalist heaven, an open market oasis of privatization and free enterprise seemingly designed by the economics department at Chicago University (Davis, 2007), a fantasy city of pleasure and profit where investors are welcomed, and international business is celebrated and treated to all the modern marvels of shiny skyscrapers, luxury hotels, fancy restaurants, golf tournaments, horse-racing events such as the Dubai World Cup (the richest horse race on earth), designer shopping outlets and conspicuous consumption, in a tax-free haven built on the back-breaking labour and casual humiliation of a meanly remunerated non-unionized workforce predominantly from the Asian sub-continent.

Whilst not remotely populous enough to be categorized as a mega-city, Dubai has become synonymous with irrepressible gusto, super-fast urbanism, triumphal architecture, and gigantism, gaining an international profile through its construction and marketing of numerous outrageously ambitious and hugely expensive spectacular mega-projects. Seemingly replaced by a full-size model of itself, Dubai appears to have taken René Descartes' contention that a truly great city should be 'an inventory of the possible', a place of imagination, to the point of parody. The Palm Islands (a trilogy of not-yet-completed artificial islands (Palm Jumeirah, Palm Jebel Ali, and Palm Deira) constructed by pumping stone and marine sand from the bottom of the Persian Gulf) and The World (an artificial archipelago of small man-made islands shaped into the continents of the earth so as to represent a map of the world) are mega-projects so gargantuan as to be identifiable from space. Meanwhile, beneath the sea there is Hydropolis, the world's first sea-bottom hotel resort - a wonder that appears to have left the pages of a Jules Verne novel, it covers some 27 acres and contains 220 luxury suites. Elsewhere, a skinny spike, the telescoping Burj Khalifa skyscraper, is the world's tallest building and structure, dominating Dubai's emerging Manhattanmanque skyline with a watching radiance akin to the black obelisk in Kubrick's 2001: A Space Odyssey.

And the visual overkill and list of surreal and alien 'world-class projects' (assorted jumbo-size ephemera) goes on: the Burj Al-Arab hotel (the world's only $7^{*}$ hotel); Dubailand (a fantasy theme park more than twice the size of Walt Disney Resort in Florida); Ski-Dubai (an indoor ski mountain, while outside it is a baking 49 degrees centigrade); the Al Maktoum International Airport (planned to be the world's largest passenger and cargo hub); the Dubai Mall (one of the world's largest shopping malls); the $\$ 1.5$ billion Atlantis resort complex, to name but a few. However, alongside those 'flagship' developments, that have drawn the world's attention to Dubai as a tourist destination (a kind of Las Vegas on steroids) and market for property speculation, are a number of large-scale developments that overtly seek to install Dubai with the functions and capacity of a global city. Eschewing the ideas of an urban sociologist such as Jane Jacobs (1961), who stressed the importance of 
street and pedestrian culture, Dubai has instead copied industrial China to attempt to become a 'global city' through constructing itself as a city of many cities: Business Bay, in the central business district of Dubai, is designed to replicate the infrastructure for international business that one finds in Manhattan with some 230 high-rise buildings. The agendas of big business unashamedly inform Dubai's urban planning: Dubai Internet City, launched in the year 2000 as a tax-free and 100 per cent business ownership platform for the world's ICT companies, signalled the emirate's strategic ambition to place itself within the internet revolution and 'new economy'; Media City, proximate to Internet City, houses branch operations of such global media organizations as CNN and Reuters News Agency; and the list goes on, with Festival City, Dubai International Financial Centre, International City, Dubai Marina, the world's largest man-made port at the Jebel Ali free zone, and so on.

Seemingly aloof from the mega-urbanization of the developing world, Dubai is not an involuntary adjustment to 'global forces', but is rather as with Lee Kuan Yew's Singapore - a consequence of both fortuitous events and decisions made by its leaders to try to grant Dubai a raison d'être. Sheik Rashid bin Saeed Al Maktoum and then his son Sheik Mohammed bin Rashid Al Maktoum, the absolute monarchs of Dubai whose faces adorn the city-state's walls, decided, because of their lack of oil, to transform Dubai into a city of globalization, to adopt a new model for economic development dependent on foreign economies. Dubai is not in small measure the materialization, through an imagineered urbanism, of the Maktoums' terrifying can-do ambition and unfettered hyper-confidence in a master plan of grandiose schemes centred on neo-liberal ideology and globalization. To make Dubai an intercontinental crossroads, the Arab centre of the modern world, and the world's most over-the-top Guinness Book of Records destination, progress and success are measured only in new storeys added and new square footage made and occupied. To urbanize is to modernize, whatever the human and financial cost. But even dream cities have problems.

Dubai is not a just image, it is just an image. A thinly-veiled actualization of Walter Benjamin's observation that the worst alienation is turned into an aesthetic, spectacular delight. Alongside Dubai's sparkling surfaces, the glitz and glamour of its faux international aesthetic, the price of a paradise for some is paid for by the million or so migrant manual construction workers - from India, Pakistan, Sri Lanka, Bangladesh and China - who do the hard labour and live their negated lives in squalid encampments (work camps) out of view from the tourists and residents. Dubai is a greenhouse of hatred. Exposed with acuity by the organization Human Rights Watch, and described by ABC news journalists as 'Dubai's Dirty Little Secret', the debt bondage and consequent slave wages of Dubai's labourers of less than US\$1 per hour is now the subject of so many outraged commentaries that Dubai has become 
a kind of poster-child for injustice. Revealed as a Metropolis-like dystopian city-state, an atrocity where a new monstrous urban apartheid has been produced. The exuberant wealth and luxury, the excess and megalomania of Dubai's elite are consequent upon the virtual enslavement and political exclusion of its lowest-paid workers. Dubai is a non-Arab society with no social equality or democratic inclusion. Less than 10 per cent of the c.2.5 million people living in Dubai are Emiratis; everyone else is in Dubai, but not of Dubai: wealthy foreigners, expatriate workers, the servant (Filipino women) underclass, labourers who are denied citizenship and can be deported upon loss of property or employment, with no stake in the city-state. Foreigners are either in bondage (trapped) or there for their own short-term economic interests before they 'opt-out' of the 'ideal city' for good.

With no democracy, elections, or political parties, little is done to quell the inequality and injustice in Dubai precisely because the enslavement is a decision that has been made at the helm of the sheikhdom. As Spinoza said long ago, every determination is a negation. Any decision to do something is always a decision not to do something else. Dubai has made its choices and imposed those choices and will on migrant workers, but it is our moral choice - do we take 'responsibility for our responsibility', as Zygmunt Bauman would say? - as to whether we choose to exercise our freedom, to have enough responsibility to boycott, to disengage with, a Dubai that has been built on bonded labour. Given the city-state's dependence on luxury tourism and foreign direct investment, its fate is ultimately not its own. Indeed, what has undone Dubai is not the inequity of its labour relations, or the dismissive remarks of so many enraged observers, but rather the unplanned and unanticipated 'event' of the global financial crisis which arrived as if from nowhere like a sandstorm in the desert.

An extraordinary symbol of globalization and the global economic boom, Dubai has been decimated by the global financial crisis. Once one of the world's fastest growing metropoles and intercontinental hubs, the global financial crisis $(2007 / 8)$ has threatened to make Dubai appear to be a folie de grandeur, a mirage in the desert, a shattered dream, a paradise lost, as it has so explicitly married its fortunes to growing a high-rise, high-finance, high-carbon economy of non-oilrelated economic activities - FDI zones, luxury tourism, and speculative real estate:

While it may be an exaggeration to say that as goes Dubai, so goes globalization, it has become hard to imagine one without the other. More than any other place on earth, this city-state in the United Arab Emirates is the creation of worldwide commerce, a specialtybuilt magnet for the kind of hot money that seeks the quickest, highest profits and then moves on when they disappear. (Dickey, 2008: unpaginated) 
A playground for investors and starchitects alike, the emirate's dreams have turned sour, rapidly going from boom to gloom, from explosion to implosion, due to its embrace of globalization and consequent exposure to the global financial meltdown. Dubai's freewheeling economy has not been sheltered from the global shocks: equity has evaporated as property values have collapsed, numerous real estate follies litter the coastline, mega-projects have been put on hold, scaled back, or scrapped as the fortunes of the city have been exposed as overleveraged, and expatriates have fled. Following its transition from marooned desert town to hyperconnected boom town - which once seemed set to rival the growth of Shanghai - Dubai has now been exposed as a vanity city, a confidence trick, a mere fabrication of the signs of wealth based on speculation, greed, hedonism, and personal mini-utopias.

Stymied by mountains of debt, the truth of its overstretched borrowing and reliance on the 'global bubble' in the commercial real estate sector is front-page news. To race to become a 'global city', to gamble everything on building an economy on real estate, to celebrate that particular urban form, means that now Dubai appears to be at a point of so-called 'urban tilt', the moment when people and money take flight from a moribund place to the next 'hot spot' of global capitalism, to be a so-called 'bubble city' like Las Vegas, Tampa (Florida), or Riverside (California), which are similarly built on consumption and excess.

Over the past decade, Dubai has had a mixed press to say the least, attracting the most Panglossian and Cassandrian of judgements: 'Miracle City' (because of its booming property market) and 'Evil Paradise' (because of its appalling treatment of low-skilled migrants), 'MiddleEastern Shangri-La' (because of its love of wealth and luxurious consumption) and 'Disneyland in the Desert' (because of its sickening kitsch hyperreality), 'the Switzerland of the Gulf' (because of its - not always transparent - role in international finance) and 'Bangkok of the Middle East' (because of the ubiquity of sex workers), 'Dubai Inc.' (because of its entrepreneurial management) and 'Creditopolis' (because of its indebtedness), are just some of the descriptions that the city-state has attracted.

Dubai is both remarkable and sinister. However, it is the fact that Dubai is not - like Singapore or Tel Aviv - a bloated mega-city that may be essential to its advantage and long-term success. Unburdened by its size, Dubai does not face the problems and challenges that exploding populations bring to regional rivals such as Cairo, Tehran, and Mumbai, and so has a certain competitive advantage over such mega-cities on the globally interconnected urban world stage. Indeed, the problems that the ongoing 2007/8 global financial crisis bring to Dubai are, the emirate hopes, nothing when compared to the challenges facing the world's meta-cities, mega-cities, and the hundreds of other cities across the developing world. However, it is worth noting that with regard to its global city ambitions Dubai is currently facing its point of death. When the 
Burj Dubai skyscraper was renamed the Burj Khalifa in deference to the emirate's bail-out from its paternal neighbour, Dubai was forever fixed in the eyes of the world as a regional, not a global, hub for business, exploitation, and strictly controlled hedonism. As the emirate's development as a corporate city (Kanna, 2011), expatriate paradise and migrant worker hell remains stalled, we must hope that, in contrast to apologists for Dubai's labour practices as a form of postcolonial development (e.g. see Roy, 2011: 320-23), the demand for bonded migrant labour will continue to be eroded by the financial crisis. Economic failure and the stalling of construction is undoubtedly how many of those trapped in Dubai will lose their chains.

\section{References}

Davidson CM (2008) Dubai: The Vulnerability of Success. New York: Columbia University Press.

Davis M (2007) Sand, fear, and money in Dubai. In: Davis M and Monk DB (eds) Evil Paradises: Dreamworlds of Neoliberalism. New York: The New Press, pp. 48-68.

Dickey C (2008) Is Dubai's party over? The glitzy façade shows some cracks. Newsweek, 6 December. Available at: http://www.newsweek.com/2008/12/05/ is-dubai-s-party-over.html (accessed 6 August 2014).

Jacobs J (1961) The Death and Life of Great American Cities. New York: Modern Library Edition.

Kanna A (2011) Dubai: The City as Corporation. Minneapolis: University of Minnesota Press.

Roy A (2011) Postcolonial urbanism: Speed, hysteria, mass dreams. In: Roy A and Ong A (eds) Worlding Cities: Asian Experiments and the Art of Being Global. Oxford: Wiley-Blackwell, pp. 307-335.

Richard G Smith is Co-Director of the Centre for Urban Theory at Swansea University in the UK. His writings have pioneered relational approaches in urban studies and are amongst the most highly-cited in the world.

This commentary is part of a Special Section on The Urban Problematic II, edited by Ryan Bishop and John Phillips. For extra material see: theoryculturesociety.org. 